\title{
Integrated Water Resources Management under different hydrological, climatic and socio-economic conditions
}

\author{
Edda Kalbus • Thomas Kalbacher • Olaf Kolditz • \\ Elisabeth Krüger · Jörg Seegert • Gunda Röstel • \\ Georg Teutsch $\cdot$ Dietrich Borchardt $\cdot$ Peter Krebs
}

Received: 17 August 2011/Accepted: 23 August 2011/Published online: 9 September 2011

(C) Springer-Verlag 2011

\section{Introduction}

Around 900 million people currently have no access to safe drinking water and around 2.6 billion people live without adequate sanitation (WHO/UNICEF 2010). This situation has serious impacts on the health of these people, but also on the economy of the concerned countries and regions. Following the Millenium Summit in 2000, the United Nations agreed upon the Millennium Development Goals (MDG). One of these goals is to reduce the number of people without access to safe drinking water and without sanitation by half by the year 2015. Water resources management is a prerequisite for all the water- and health-related MDG (World Water Assessment Programme 2009).

The appropriate management of water resources is essential for achieving sustainable development including social and economic development, poverty reduction and equity, and sustainable environmental services (World Water Assessment Programme 2009; Teutsch and Krüger 2010). The fact that water is a natural resource, an integral part of the ecosystem and a social and economic good is recognized in the concept of Integrated Water Resources Management (IWRM), which has been defined by the Technical Committee of the Global Water

E. Kalbus $(\bowtie) \cdot$ T. Kalbacher · O. Kolditz · E. Krüger ·

G. Teutsch - D. Borchardt

Helmholtz Centre for Environmental Research-UFZ,

Permoserstraße 15, 04318 Leipzig, Germany

e-mail: edda.kalbus@ufz.de

O. Kolditz · J. Seegert - D. Borchardt · P. Krebs

Technische Universität Dresden, 01062 Dresden, Germany

G. Röstel

Stadtentwässerung Dresden, Scharfenberger Straße 152,

01078 Dresden, Germany
Partnership (GWP) as "a process which promotes the coordinated development and management of water, land and related resources, in order to maximize the resultant economic and social welfare in an equitable manner without compromising the sustainability of vital ecosystems" (GWP 2000).

The International Water Research Alliance Saxony (IWAS) aims to contribute to an IWRM in hydrologically sensitive regions by developing specific system solutions as a response to water-related problems worldwide. Overarching objectives are (1) to generate interdisciplinary system understanding for a sustainable management of water resources in response to natural and social changes, (2) to develop and implement sitespecific methods, models and technologies for water management, (3) to develop and apply site-specific management concepts and implementation strategies involving local governance structures and participatory processes, and (4) to contribute to the transfer of existing and newly acquired knowledge into the model regions (capacity development). Research questions concerning worldwide water problems in the context of global change are tackled in the project. Specific aspects of representative priority problems of water management are examined in selected regions (Fig. 1), where a pronounced sensitivity with regard to the investigated aspects is identified. All relevant water compartments, the managed systems (drinking water, wastewater, irrigation), the status and function of natural ecosystems, as well as anthropogenic influences (climate, land use, etc.) are investigated, where they appear most sensitive. In order to link the regions and form the potential to later on integrate the findings to a holistic IWRM concept, certain aspects relevant to all model regions are treated in cross-cutting sub-projects. These aspects include 
Fig. 1 The model regions of the IWAS project

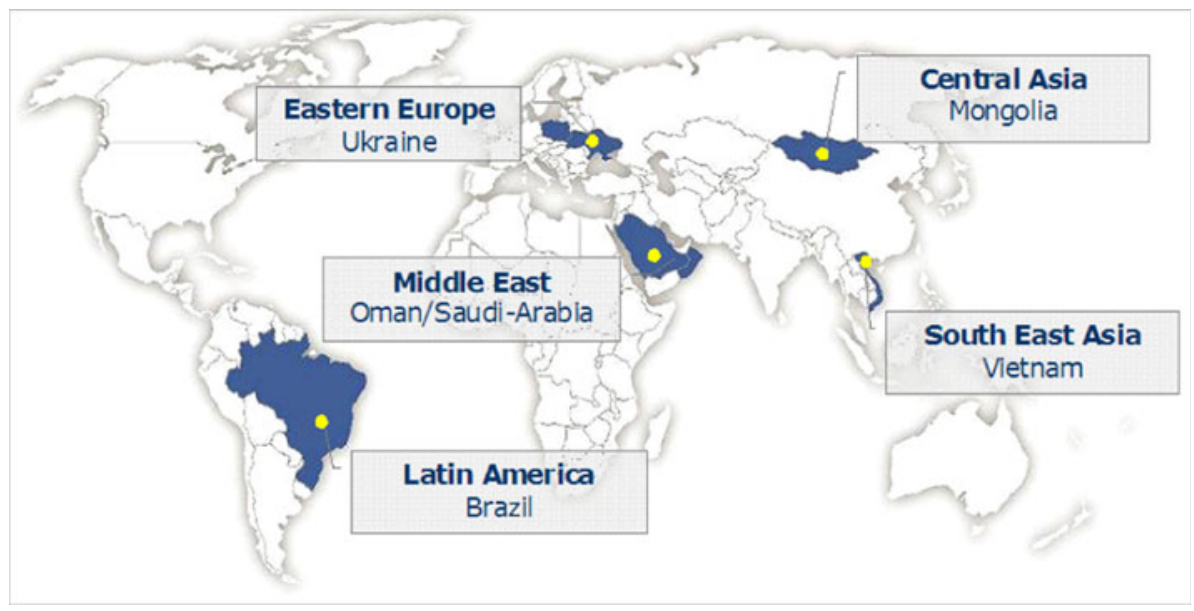

systems analysis, scenario development and modeling, institutional prerequisites for water resources management, capacity development, and technology development and implementation.

In order to help the reader to assign the papers of this issue to the structure of IWAS, a brief overview is given of the contents and the main emphasis of the IWAS subprojects.

\section{Scenario and system analysis}

The focus of the cross-cutting topic "Scenario and system analysis" lies on the development and provision of applicable tools to analyze aspects of water resources management issues. The idea of developing a ToolBox was to provide interfaces for combining existing simulation tools to answer specific questions related to coupled hydrosystems (Kolditz et al. 2008; Kalbacher et al. 2011a). Examples are (1) investigating the interaction of roots and soil to better understand the mechanisms of water uptake (Kalbacher et al. 2011b), (2) studying the interaction between surface and subsurface water in the River Bug model area in particular to better understand the mechanisms of hydrograph separation and mass exchange between different hydro-compartments (Delfs et al. 2009, 2011), (3) setting up models of the wastewater systems based on little information (Blumensaat et al. 2011) and linking them with a river model, (4) climate projections (Pavlik et al. 2011), (5) future scenarios development (Schanze et al. 2011). The development of concepts and tools for data integration and visualization (Rink et al. 2011) became an important prerequisite for hydrological process analysis. Several web applications have been developed and implemented for the model regions in Vietnam and Brazil in order to handle the amount and heterogeneity of data in an adequate way.

\section{Eastern Europe}

In this region the focus lies on the improvement of surface water quality within the Western Bug River which rises in the Ukraine, then partly borders the Ukraine and Poland. While showing a good morphological quality (Scheifhacken et al. 2011), the river is strongly polluted with inputs from agriculture, industry, urban areas and mining activities (Blumensaat et al. 2011; Delfs et al. 2011; Ertel et al. 2011; Tavares Wahren et al. 2011). Two general research questions are (1) can the lessons learned from the newly formed German states be useful for improving the water quality in the Bug Area and (2) what are the consequences for the implementation of the EU Water Framework Directive as the Bug River crosses the EU border.

\section{Central Asia}

Research in Central Asia/Mongolia in the pilot catchment of the Kharaa River focuses on key elements of IWRM strategies in a semi-arid continental climate setting under dynamic global change processes (especially climate, land use, and demographic changes). The foci are (1) regional hydrological processes (Vetter et al. 2011), (2) land use impacts on the ecological quality of surface waters (Hartwig et al. 2011), (3) innovative decentralized wastewater management strategies backed with an integrated analysis (Sigel et al. 2011) and (4) institutional settings as a prerequisite for effective implementation (Horlemann and Dombrowsky 2011).

\section{South East Asia}

In many areas of Hanoi, Vietnam, problems of flooding and water pollution occur frequently. The general objective of 
this sub-project is the development of a sustainable drainage concept based on the existing master plan for the Long Bien district, Hanoi, and its integration into existing local and regional water cycles with the following aims: (1) supporting further urban development by using systems which are adaptive to fast growth, (2) protection and recharge of groundwater resources, (3) flood protection and (4) improvement of the quality of surface and groundwater.

\section{Middle East}

New solutions for a sustainable management of the scarce water resources in (semi-) arid regions are explored in Oman (Grundmann et al. 2011) and Saudi Arabia (Pfletschinger et al. 2011). Research topics are (1) the large-scale, highly precise determination of groundwater recharge, (2) saltwater intrusion (Kalbacher et al. 2011a), (3) the storage and use of ephemeral streams (artificial groundwater recharge), and (4) the optimization of water use in agriculture (Schütze et al. 2011). Modern hydrogeologic tracer and isotopic methods are used and innovative regional models are developed as a basis for a sustainable management.

\section{Latin America}

Accelerated non-planned urbanization and changes in land use have caused a strong impact on the water resources of Brazil's capital Brasília. According to the local water supplier, already in 2010 water demand has exceeded the system's supply capabilities. Here, the main objective is to develop an IWRM covering (1) the general natural framework (climate, hydrological cycle, land use, etc.) (Lorz et al. 2011), (2) the drinking water supply systems (Vasyukova et al. 2011), (3) wastewater treatment and sewer systems and management, and (4) sediment characteristics (Franz et al. 2011).

\section{Transfer and application}

Developing adequate concepts of knowledge transfer and capacity development (CD) is an essential component of the IWAS initiative. CD concepts are developed which are tailored to the regional conditions to improve local capacity. Such measures include the vocational training of people working in the field of water resources management, support of scientific education and curricula development, knowledge exchange, and the exchange of scientific staff. It is crucial for the success of such measures to elaborate functioning networks in both the academic and the practice arena in order to ensure the mutual exchange of experiences (Leidel et al. 2011).

This special issue presents selected aspects of the IWAS project. However, it provides a first insight into the achievements and ongoing research activities. At the same time it indicates the wide horizon of aspects related to IWRM and the need to later on integrate these aspects. More information can be found at http://www.iwas-initiative.de.

Acknowledgments The work presented in this special issue was supported by funding from the Federal Ministry for Education and Research (BMBF) in the framework of the project "IWAS-International Water Research Alliance Saxony". We are very grateful for the support of Gunter Dörhöfer (Editor of Environmental Earth Sciences) at all stages of the preparation of this issue. We would also like to thank the many manuscript reviewers for their contributions to improve the quality of this issue.

\section{References}

Blumensaat F, Wolfram M, Krebs P (2011) Sewer model development under minimum data requirements. Environ Earth Sci. doi: 10.1007/s12665-011-1146-1 (this issue)

Delfs J-O, Park C-H, Kolditz O (2009) A sensitivity analysis of Hortonian flow. Adv Water Resour 32(9):1386-1395

Delfs JO, Blumensaat F, Wang W, Krebs P, Kolditz O (2011) Coupling hydrogeological with surface runoff model in a Poltva case study in Western Ukraine. Environ Earth Sci. doi: 10.1007/s12665-011-1285-4 (this issue)

Ertel A-M, Lupo A, Scheifhacken N, Bodnarchuk T, Manturova O, Berendonk T, Petzoldt T (2011) Heavy load and high potential. Anthropogenic pressures and their impacts on the water quality along a lowland river (Western Bug, Ukraine). Environ Earth Sci. doi:10.1007/s12665-011-1289-0 (this issue)

Franz C, Makeschin F, Roig HL, Schubert M, Weiß H, Lorz C (2011) Sediment characteristics and sedimentations rates of a small river in Western Central Brazil. Environ Earth Sci (this issue)

Grundmann J, Schütze N, Schmitz G-H, Al Shaqsi S (2011) Towards an integrated arid zone water management using simulation based optimisation. Environ Earth Sci. doi:10.1007/s12665011-1253-z (this issue)

GWP (2000) Integrated Water Resources Management. Global Water Partnership, Technical Advisory Committee (TAC) Background Papers No. 4, Stockholm

Hartwig M, Theuring P, Rode M, Borchardt D (2011) Sources of suspended sediments and its implications on ecosystem functions in the Kharaa River (Mongolia). Environ Earth Sci. doi: 10.1007/s12665-011-1198-2 (this issue)

Horlemann L, Dombrowsky I (2011) Institutionalizing IWRM in developing and transition countries-the case of Mongolia. Environ Earth Sci. doi:10.1007/s12665-011-1213-7 (this issue)

Kalbacher T, Schneider CL, Wang W, Hildebrandt A, Attinger S, Kolditz O (2011a) Parallelized modelling of soil-coupled 3D water uptake of multiple root systems with automatic adaptive time step control. Vadose Zone J 10:727-735. doi:10.2136/ vzj2010.0099

Kalbacher T, Delfs JO, Shao H, Wang W, Walther M, Samaniego L, Schneider C, Musolff A, Centler F, Sun F, Hildebrandt A, Liedl R, Borchardt D, Krebs P, Kolditz O (2011b) The IWASToolBox: software coupling for an integrated water resources management, Environ Earth Sci. doi:10.1007/s12665-0111270 -y (this issue) 
Kolditz O, Delfs JO, Bürger CM, Beinhorn M, Park C-H (2008) Numerical analysis of coupled hydrosystems based on an objectoriented compartment approach. J Hydroinformatics 10(3): 227-244

Leidel M, Niemann S, Hagemann N (2011) Capacity development as key factor for ntegrated water resources management (IWRM) improving water management in the Western Bug River Basin, Ukraine. Environ Earth Sci. doi:10.1007/s12665-011-1223-5 (this issue)

Lorz C, Abbt-Braun G, Bakker F, Borges P, Börnick H, Fortes L, Frimmel FH, Gaffron A, Hebben N, Höfer R, Makeschin F, Neder K, Roig LH, Steiniger B, Strauch M, Walde D, Weiß H, Worch E, Wummel J (2011) Challenges of an integrated water resource management for the Distrito Federal, Western Central Brazil-climate, land use and water resources. Environ Earth Sci. doi:10.1007/s12665-011-1219-1 (this issue)

Pavlik D, Söhl D, Pluntke T, Mykhnovych A, Bernhofer C (2011) Dynamic downscaling of global climate projections for Eastern Europe with a horizontal resolution of $7 \mathrm{~km}$. Environ Earth Sci. doi:10.1007/s12665-011-1081-1 (this issue)

Pfletschinger H, Engelhardt I, Piepenbrink M, Königer F, Schuhmann R, Kallioras A, Schüth C (2011) Soil column experiments to quantify vadose zone water fluxes in arid settings. Environ Earth Sci. doi:10.1007/s12665-011-1257-8 (this issue)

Rink K, Kalbacher T, Kolditz O (2011) Visual data management for hydrological analysis. Environ Earth Sci. doi:10.1007/ s12665-011-1230-6 (this issue)

Schanze J, Trümper J, Burmeister C, Pavlik D, Kruhlov I (2011) A methodology for dealing with regional change in integrated water resources management. Environ Earth Sci. doi:10.1007/ s12665-011-1311-6 (this issue)

Scheifhacken N, Haase U, Gram-Radu L, Kozovyi R, Berendonk T (2011) The comparison and suitability of assessment methods to identify the hydro-morphological status of a transboundary river in the Ukraine. Environ Earth Sci. doi:10.1007/s12665-0111218-2 (this issue)

Schütze N, Kloss S, Lennartz F, Bakri A, Schmitz GH (2011) Optimal planning and operation of irrigation systems under water resource constraints in Oman considering climatic uncertainty. Environ Earth Sci. doi:10.1007/s12665-011-1135-4 (this issue)

Sigel K, Altantuul K, Basandorj D (2011) Household needs and demand for improved water supply and sanitation in peri-urban ger areas: the case of Darkhan, Mongolia. Environ Earth Sci. doi: 10.1007/s12665-011-1221-7 (this issue)

Tavares Wahren F, Tarasiuk M, Mykhnovych A, Kit M, Feger KH, Schwärzel K (2011) Estimation of spatially distributed soil information. Dealing with data shortages in the Western Bug Basin, Ukraine. Environ Earth Sci. doi:10.1007/s12665-0111197-3 (this issue)

Teutsch G, Krüger E (2010) Water Science Alliance-White Paper. http://www.water-research-horizon.ufz.de/data/ WaterScienceAlliance_WhitePaper_FINAL13130.pdf

Vasyukova E, Uhl W, Braga F, Neder K (2011) Challenges of drinking water production from surface water sources in Brasilia DF, Brazil. Environ Earth Sci. doi:10.1007/s12665-011-1308-1 (this issue)

Vetter S, Schaffrath D, Bernhofer C (2011) Spatial Simulation of evapotranspiration of semi-arid Inner Mongolian grassland based on MODIS and eddy covariance data. Environ Earth Sci. doi: $10.1007 / \mathrm{s} 12665-011-1187-5$ (this issue)

WHO/UNICEF (2010) World Health Organization and United Nations Children's Fund Joint Monitoring Programme for water supply and sanitation (JMP). Progress on sanitation and drinking water-2010 update. WHO Press, Geneva

World Water Assessment Programme (2009) The United Nations World Water Development Report 3: water in a changing world. UNESCO/Earthscan, Paris/London 